\title{
Review
}

\section{Global powers of horror: Security, politics, and the body in pieces}

\author{
François Debrix \\ London and New York: Routledge, 2017, 158 pp., \\ ISBN: 9780415741422
}

Contemporary Political Theory (2018) 17, S193-S196. https://doi.org/10.1057/s41296017-0163-6; published online 5 October 2017

Much has been written about extreme violence against individuals and their bodies from the perspective of 'biopolitics'. According to Foucault, biopolitics emerges when 'the right to punish' shifts 'from the vengeance of the sovereign to the defence of society' (1977, p. 90). Biopolitics manages life 'in the name of life necessity', administrating - among others - illness, sanitary conditions in the towns and security regimes. Yet, as Giorgio Agamben and Achille Mbembe have argued, while Foucault's insight into biopolitical power's management and production of life is crucial, the right to decide life and death is never completely separated from the exercise of sovereign power and its geopolitical manifestations. Thus, as Mbembe suggests, biopolitical power is also concerned with 'the subjugation of life to the power of death' (2003, p. 39). Agamben adds that 'if there is a line in every modern state marking the point at which the decision on life becomes a decision on death, and biopolitics can turn into thanatopolitics, the line no longer appears today as a stable border dividing two clearly distinct zones' (1998, p. 122). When biopolitics becomes an essential function of sovereign power - what Mbembe terms 'the creation of death worlds' $(2003$, p. 40) - it becomes the main object of geopolitical power.

In his most recent book Global Powers of Horror, François Debrix takes a different route. He claims that, in contemporary manifestations of bio-geo-politicotheological violence and war, the life and death of populations and individual bodies is not the main object. What is of concern, instead, is what Debrix calls 'the horror of the dismantling of the human' (p. 97). This does mean that horror replaces 'biopower with necropower or biopolitics with thanatopolitics. Rather, horror directly assaults human life, including the capacity to die a human death' (p. 5). Put differently, horror's extreme violence 'breaks down the human body into parts, bits, pieces, shreds of flesh, tissue, pulp, and fluids, and it renders human matter indistinct from non-human materiality' (p. 6).

(C) 2017 Macmillan Publishers Ltd. 1470-8914 Contemporary Political Theory Vol. 17, S4, S193-S196 
Debrix's book is a critical attempt to theorise 'contemporary regimes of horror' (p. 6). In doing so, it focuses on body parts, pieces and fragments. Looking at horror's contemporary instantiations, the book aims to retool theory to accommodate oppressed post-human, non-human and inhuman perspectives. Horror, Debrix insinuates, makes human matter irrelevant.

The book comprises just four chapters and an introduction. Instead of a conclusion, it features an epilogue. Each of the four chapters focuses on a particular (geo)political destruction of bodily fragments - the biopolitics of the camp/camplife, katechontic (from the Greek for 'to hold down') sovereignty and its violent security politics, disseminated body parts of victims, beheadings and remnants of non-human and human matter post 9/11. Each of these particular manifestations of horror is examined to understand and challenge the social regime of terror and security politics, suggesting that they 'are part of the same motion, of the same physics of movement, of the same dynamic and fluid domain where falling, rising, falling again, and rising again (and so on and so forth) are normal occurrences' (p. 61).

The book helps us make sense of the horror inherent in terror and security politics that function beyond biopolitics and thanatopolitics. In contrast to terror and security politics and their mobilisation of lives and bodies within the horizon of biopolitics and thanatopolitics, what we are left with horror 'is a sort of world without humans' (p. 6). Therefore, horror is marked with a 'new materiality, a new vibrancy, or a new liveliness' (p. 130). Horror renders human life powerless; it reflects the crisis of the human, of humanity itself.

However, the book distances itself from post-humanist, new materialist or vibrant matter scholarship since they fail 'to rid themselves of the metaphysics of human substance' (p. 8). In this sense, Debrix's notion of horror 'seeks to put an end to the metaphysics of substance' (p. 8). Unlike horror, terror and security politics sustain rather than challenge 'the continued dominant presence of the metaphysics of substance' (p. 63). Whereas terror remains a generative principle of formation for security, horror is what 'our' security politics 'cannot confront and must representationally cast away' (p. 63). The power of horror thus transcends the threshold of human substance.

In this manner, horror unsettles the belief that this world is only created for us, for human beings and their bodies. In other words, what horror often leaves behind is neither a 'world-with-us' nor a 'world-for-us' but a 'world-without-us', to borrow Eugene Thacker's language (2011, p. 9). In horror's world, the ontological primacy and superiority of the human no longer exists. Thus, what takes place in horror is a radical undecidability, a critical guarantee that 'humanity's ontological priority and superiority will no longer be claimed with metaphysical and political certainty' (p. 114). Horror offends or attacks the value or dignity of the human in particular and of humanity in general. 
So where does Debrix's theorisation of horror leave us? Horror, it seems, has been monopolised by two regimes: security politics and terror. Security politics is katechontic: it legitimises the existing order. It is the sovereign's intent that attempts to delay the coming of end times. In this sense, it is fundamental to the operation of contemporary sovereign power and its violent politics more generally. The katechon requires that operations of security politics be incessantly and intensely performed so that the monopoly on violence and horror may remain within the boundaries of sovereign power. In other words, katechontic sovereignty tries to keep a monopoly on the means of violence and horror by preventing terror from taking it over. It sees violence and horror in the hands of terror as a danger undermining the existing order.

However, the katechontic logic of contemporary sovereignty is now less a matter of holding back the end, than of producing, creating and proliferating the vital forces of being-in-formation that threaten the eternity of the sovereign rule. It accelerates rather than restrains the forces of terror. Precisely in this sense, katechontic sovereignty departs from the earlier theological paradigm of sovereignty that is so central to Carl Schmitt, since it wants to exercise infinite governance in this world over the 'infinity of finite ends' (Dillon, 2015, p. 9). In other words, contemporary katechontic sovereignty demands an acceleration of the forces of terror, for acceleration allows the enemy to reveal herself and press the button. Thus, there is always a need for katechontic sovereignty to think in terms of eschatological terrors, or to mobilise the spectre of fear and terror in changing circumstances. The exercise of katechontic sovereignty is thus incitatory, in that it seeks to actively produce (and profit from) the so-called terror of the eschaton of time. Eschatological terror, by contrast, aims to end the temporal order of things.

Debrix nicely discusses the close kinship between katechontic sovereignty and security politics, demonstrating how they mirror each other. However, in Debrix's book, the term neoliberalism is never mentioned. Insofar as the contemporary regime of governmentality is neoliberal, neoliberalism constitutes the problematic of critique today. As such, terror is inseparable from neoliberalism. Conjured by the established social regimes and principles, neoliberalism must produce its most necessary social and political enemy, terror. In other words, in contemporary society, terror has become a generative principle of formation for the neoliberal order.

Yet, despite his failure to examine the 'intimate partnership' between terror and neoliberalism, Debrix's book is a brilliant attempt to theorise horror and its contemporary geopolitical instances by showing how horror dismantles the human condition itself. The book shines splendidly when it addresses the possibility of 'reclaiming the horror of the eschaton' (p. 48). For Debrix, although the eschaton is enslaved by the sacred sovereign order and terror, it could nevertheless be rescued from them both. Perhaps, then, the time has already arrived to replace katechontic sovereignty and eschatological terror with the spectre of a different eschaton. It is at

(C) 2017 Macmillan Publishers Ltd. 1470-8914 Contemporary Political Theory Vol. 17, S4, S193-S196 S195 
this point that Debrix calls for a new notion of 'eschatological horror', which is 'beyond good and evil' (p. 50). Eschatological horror, Debrix suggests, can open up a new space, distinct from sovereign violence and the politics of security and terror. It can give rise to a new life in which 'neither humans nor non-humans are recombined. Rather, some other, new, as of yet unseen material emerges and comes to life' (p. 130). Therefore, eschatological horror has an interruptive and a transgressive capacity, which illuminates and actualises new possibilities for radical change in our current age of collective despair. As an assault on the metaphysics of substance, Debrix's eschatological horror materialises the becoming of a new human/humanity without prophets, connected to a new 'recombined, or recomposed human matter' to come (p. 131).

\section{References}

Agamben, G. (1998) Homo Sacer: Sovereign Power and Bare Life. Stanford, CA: Stanford University Press.

Dillon, M. (2015) Biopolitics of Security: A Political Analytic of Finitude. London: Routledge.

Foucault, M. (1977) Discipline and Punish: The Birth of the Prison. London: Penguin.

Mbembe, A. (2003) Necropolitics. Public Culture 15(1): 11-40.

Thacker, E. (2011) In the Dust of this Planet: Horror of Philosophy, Vol. 1. Winchester: Zero Books.

Ali Rıza Taşkale

Near East University, North Nicosia, North Cyprus aliriza.taskale@neu.edu.tr 